\title{
Deiodination Activity in Extrathyroidal Tissues of the Atlantic Hagfish, Myxine glutinosa
}

\author{
JENNIFER M. MCLEESE, ${ }^{1}$ GLENDA M. WRIGHT, ${ }^{2}$ JOHN H. YOUSON, ${ }^{3}$ \\ AND J. GEOFFREY EALES ${ }^{1 *}$ \\ ${ }^{1}$ Department of Zoology, University of Manitoba, Winnipeg, Manitoba, \\ Canada R3T 2 N2 \\ ${ }^{2}$ Department of Anatomy and Physiology, Atlantic Veterinary College, \\ University of Prince Edward Island, Charlottetown, Prince Edward Island, \\ Canada C1A $4 P 3$ \\ ${ }^{3}$ Department of Zoology and Division of Life Sciences, University of Toronto \\ at Scarborough, Ontario, Canada M1C 1A4
}

\begin{abstract}
We measured low substrate ( $<1 \mathrm{nM}$ ) thyroid hormone ( $\mathrm{TH})$ deiodination activities in liver, muscle, intestine, and brain microsomes of Atlantic hagfish fasted for 2 weeks and found extremely low thyroxine $\left(\mathrm{T}_{4}\right)$ outer-ring deiodination $\left(\mathrm{T}_{4} \mathrm{ORD}\right)$ and inner-ring deiodination $\left(\mathrm{T}_{4} \mathrm{IRD}\right)$ as well as 3,5,3'-triiodothyronine $\left(\mathrm{T}_{3}\right)$ IRD activities. $\mathrm{T}_{3} \mathrm{ORD}, 3^{\prime}, 5^{\prime}$-triiodothyronine $\left(\mathrm{rT}_{3}\right) \mathrm{ORD}$ and $\mathrm{rT}_{3} \mathrm{IRD}$ activities were undetectable. Hagfish deiodinating pathways resembled those of teleosts in requiring a thiol cofactor (dithiothreitol, DTT) and in their inhibition by established deiodinase inhibitors and by $\mathrm{TH}$ analogues. However, under optimal $\mathrm{pH}$ and DTT conditions intestinal T $\mathrm{ORD}_{4}$ activity exceeded that of liver about 10 -fold. This contrasts with the situation in teleosts but resembles that reported recently in larval and adult lampreys, suggesting the intestine as a primary site of TH deiodination in lower craniates. J. Exp. Zool. 287:445-452, 2000. (c) 2000 Wiley-Liss, Inc.
\end{abstract}

Deiodination of thyroid hormones (TH) in extrathyroidal tissues is crucial for TH interconversion and regulation of thyroidal status (McNabb, '92). The main $\mathrm{TH}$ secreted from the thyroid is thyroxine $\left(\mathrm{T}_{4}\right)$, but for most target tissues $\mathrm{T}_{4}$ is relatively inactive and requires loss of an outer-ring iodine to form bioactive 3,5,3'-triiodothyronine $\left(\mathrm{T}_{3}\right)$. $\mathrm{T}_{4}$ outer-ring deiodination $\left(\mathrm{T}_{4} \mathrm{ORD}\right)$ occurs in liver and other tissues due to enzymatic deiodination activity found mainly in the endoplasmic reticulum. $\mathrm{T}_{4}$ also undergoes inner-ring deiodination ( $\mathrm{T}_{4} \mathrm{IRD}$ ) to form the inactive $\mathrm{T}_{3}$ isomer, 3,3',5'-triiodothyronine or reverse $\mathrm{T}_{3}\left(\mathrm{rT}_{3}\right)$. $\mathrm{T}_{3}$ itself can undergo inner-ring deiodination ( $\left.\mathrm{T}_{3} \mathrm{IRD}\right)$ to form inactive $3,3^{\prime}$-diiodothyronine $\left(3,3^{\prime}-\mathrm{T}_{2}\right)$, but significant $\mathrm{T}_{3} \mathrm{ORD}$ activity has not been reported. $\mathrm{rT}_{3}$ can also be deiodinated from the outer ring to form $3,3^{\prime}-T_{2}$. The activities of these various deiodination pathways can regulate the formation and degradation of biologically active $\mathrm{T}_{3}$ in peripheral tissues and also salvage iodine prior to $\mathrm{TH}$ excretion (Eales and Brown, '93).

Several forms of TH deiodinating activity exist in teleost fish (MacLatchy and Eales, '92; Leatherland, '94; Mol et al., '93, '97, '98; Frith and Eales, '96; Orozco et al., '97). The teleost deiodinases resemble those of tetrapods in having a selenocy- steine group at their active site (Valverde-R et al., '97; Sanders et al., '97), and all known deiodinases have likely evolved from a single ancestral selenocysteine-containing protein (St. Germain and Galton, '97). Not unexpectedly, the teleost deiodinases resemble the mammalian types I, II, and III deiodinases in structure and in some aspects of their function, but they differ in several other respects (Mol et al., '98; Finnson et al., '99). We have recently shown that an agnathan, the sea lamprey (Petromyzon marinus), also exhibits $\mathrm{T}_{4} \mathrm{ORD}, \mathrm{T}_{4} \mathrm{IRD}$, and $\mathrm{T}_{3} \mathrm{IRD}$ activities in liver and particularly intestinal tissue (Eales et al., '97). Furthermore, these activities change in response to developmental state (Eales et al., '99). Thus regulation of thyroidal status through the adjustment of the activities of extrathyroidal deiodinase enzymes had evolved at a phyletic level represented by an extant vertebrate with an ancient lineage.

Hagfish have a more ancient history than the

Grant sponsor: Natural Sciences and Engineering Council of Canada; Grant numbers: GP1965 (J.G.E.), GP5945 (J.H.Y.).

*Correspondence to: J.G. Eales, Department of Zoology, University of Manitoba, Winnipeg, Manitoba, Canada R3T 2N2. E-mail: ealesjg@ms.umanitoba.ca

Received 7 December 1999; accepted 3 July 2000 
lampreys from which they separated over 550 million years ago (Forey and Janvier, '93). Hagfish possess thyroid tissue (Gorbman, '63; Henderson and Gorbman, '71; Fujita and Shinkawa, '75), which concentrates radioiodide (Tong et al., '61; Waterman and Gorbman, '63; Suzuki, '82, '85) and which contains an unusual form of thyroglobulin (Suzuki and Gorbman, '74; Suzuki, '82; Ohmiya et al., '89). Furthermore, hagfish have significant levels of both $\mathrm{T}_{4}$ and $\mathrm{T}_{3}$ in their blood (Henderson and Lorscheider, '75; Henderson, '76; Plisetskaya et al., '83a), and TH administration alters aspects of intermediary metabolism (Plisetskaya et al., '83 a,b). However, the extent and mechanism of thyroid control by the brain-pituitary axis is not fully resolved (Fernholm and Olsson, '69; Kerkof et al., '73; Dickhoff and Gorbman, '77; Dickhoff et al., '78; Gorbman, '80). Considerable control of thyroidal status could be achieved in extrathyroidal tissues by adjusting $\mathrm{TH}$ deiodinating activities (Dickhoff and Darling, '83; Eales, '97). It is therefore of interest to study the distribution and properties of $\mathrm{TH}$ deiodinating activity in hagfish. We have examined deiodination in certain tissues of Atlantic hagfish, Myxine glutinosa.

\section{MATERIALS AND METHODS}

Hagfish (length 26-42 cm, weight 30-83.6 g, male and female) were captured by baited traps in August 1995 in Passamaquoddy Bay, New Brunswick. They were transported to the Atlantic Veterinary College, University of Prince Edward Island, where they were fasted for 2 weeks in recirculating 35-ppt seawater in $150-\mathrm{L}$ tanks at $10^{\circ} \mathrm{C}$ in the dark. They were anesthetized in
MS222 and killed by decapitation. The brain, liver, intestine, and a sample of muscle were frozen in liquid nitrogen and stored at $-80^{\circ} \mathrm{C}$ prior to shipment on dry ice to Winnipeg where they were stored at $-76^{\circ} \mathrm{C}$. Microsomes were prepared on tissues from one to three individuals (Shields and Eales, '86) and frozen at $-76^{\circ} \mathrm{C}$ for subsequent in vitro deiodination assays at $12^{\circ} \mathrm{C}$ using ${ }^{125}$ I-labeled $\mathrm{rT}_{3}, \mathrm{~T}_{4}$, or $\mathrm{T}_{3}$ as substrate (Eales et al., '97). HPLC procedures were used to separate and identify the labeled products and followed those of Sweeting and Eales ('92a), with specific conditions provided in the figure legends.

Rainbow trout (Oncorhynchus mykiss) liver microsomes were prepared by the same methods. Trout were obtained from stocks held in freshwater at the University of Manitoba under $12 \mathrm{hr}$ L:12 $\mathrm{hr} \mathrm{D}$ photoperiod and $12^{\circ} \mathrm{C}$. They were fed trout grower pellets (1\% of body weight/day). All animals were held and killed according to protocols approved by the Animal Care Committee of either the Atlantic Veterinary College (hagfish) or the University of Manitoba (trout).

\section{RESULTS \\ $T_{4}$ substrate}

Hagfish $\mathrm{T}_{4}$ deiodination activities were first surveyed on two pools of each tissue using incubation conditions $[\mathrm{pH} 7.2$, dithiothreitol (DTT) concentration $20 \mathrm{mM} ; \mathrm{T}_{4}$ substrate level $\left.<1 \mathrm{nM}\right]$ found to be optimal for salmonids. $\mathrm{T}_{4} \mathrm{ORD}$ activity in hagfish tissues $(<5 \mathrm{fmol} / \mathrm{mg}$ protein/hr) was much lower than that in trout liver (112 or 480 $\mathrm{fmol} / \mathrm{mg} / \mathrm{hr}$ ) measured in the same assay (Table 1; Fig. 1). Furthermore, hagfish intestinal and he-

TABLE 1. In vitro deiodination activities ( $\mathrm{fmol} / \mathrm{mg}$ protein $/ \mathrm{hr}$ ) measured simultaneously in hagfish tissue and rainbow trout liver using $20 \mathrm{mM}$ DTT at $\mathrm{pH} 7.2$ and $12^{\circ} \mathrm{C}$

\begin{tabular}{|c|c|c|c|c|c|c|}
\hline Study & Species & Tissue $^{\mathrm{e}}$ & $n^{\mathrm{c}}$ & $\mathrm{T}_{4} \mathrm{ORD}$ & $\mathrm{T}_{4} \mathrm{IRD}$ & $\mathrm{T}_{3} \mathrm{IRD}$ \\
\hline \multirow[t]{5}{*}{$1^{\mathrm{a}}$} & \multirow[t]{4}{*}{ Hagfish } & Liver & 6 & $3.6(1.1)$ & $1.3(0.3)$ & $2.4(1.4)$ \\
\hline & & Intestine & 6 & $1.6(0.7)$ & $1.7(0.8)$ & $8.0(4.1)$ \\
\hline & & Muscle & 6 & $1.7(1.1)$ & $1.5(0.6)$ & $5.1(2.4)$ \\
\hline & & Brain & 6 & $n \mathrm{~d}^{\mathrm{d}}$ & $4.9(1.7)$ & $11.8(4.9)$ \\
\hline & Trout & Liver & 2 & 112.0 & 3.6 & 33.9 \\
\hline \multirow[t]{5}{*}{$2^{b}$} & \multirow[t]{4}{*}{ Hagfish } & Liver & 4 & $1.5(1.0)$ & nd & $0.1(0.3)$ \\
\hline & & Intestine & 4 & $3.3(0.8)$ & nd & $3.8(1.3)$ \\
\hline & & Muscle & 4 & $0.6(0.5)$ & nd & nd \\
\hline & & Brain & 4 & $1.3(1.3)$ & nd & $0.4(0.2)$ \\
\hline & Trout & Liver & 1 & 480 & 17.1 & 5.5 \\
\hline
\end{tabular}

\footnotetext{
${ }^{\mathrm{a}} \mathrm{T}_{4}$ substrate level $0.69 \mathrm{nM} ; \mathrm{T}_{3}$ substrate level $0.89 \mathrm{nM}$.

${ }^{\mathrm{b}} \mathrm{T}_{4}$ substrate level $0.24 \mathrm{nM} ; \mathrm{T}_{3}$ substrate level $0.12 \mathrm{nM}$.

cEach " $n$ " value represents a separate pool derived from 1-3 hagfish or from 2 trout.

${ }^{\mathrm{d}}$ Activity not detectable.

e Protein concentration (mg/ml): Study 1, liver, 0.35-1.0; intestine, 0.45-0.96; muscle 0.52-0.66; brain 0.15-0.33; Study 2, liver 0.41-0.46; intestine $0.42-0.47$; muscle $0.46-0.81$; brain $0.32-0.69$.
} 

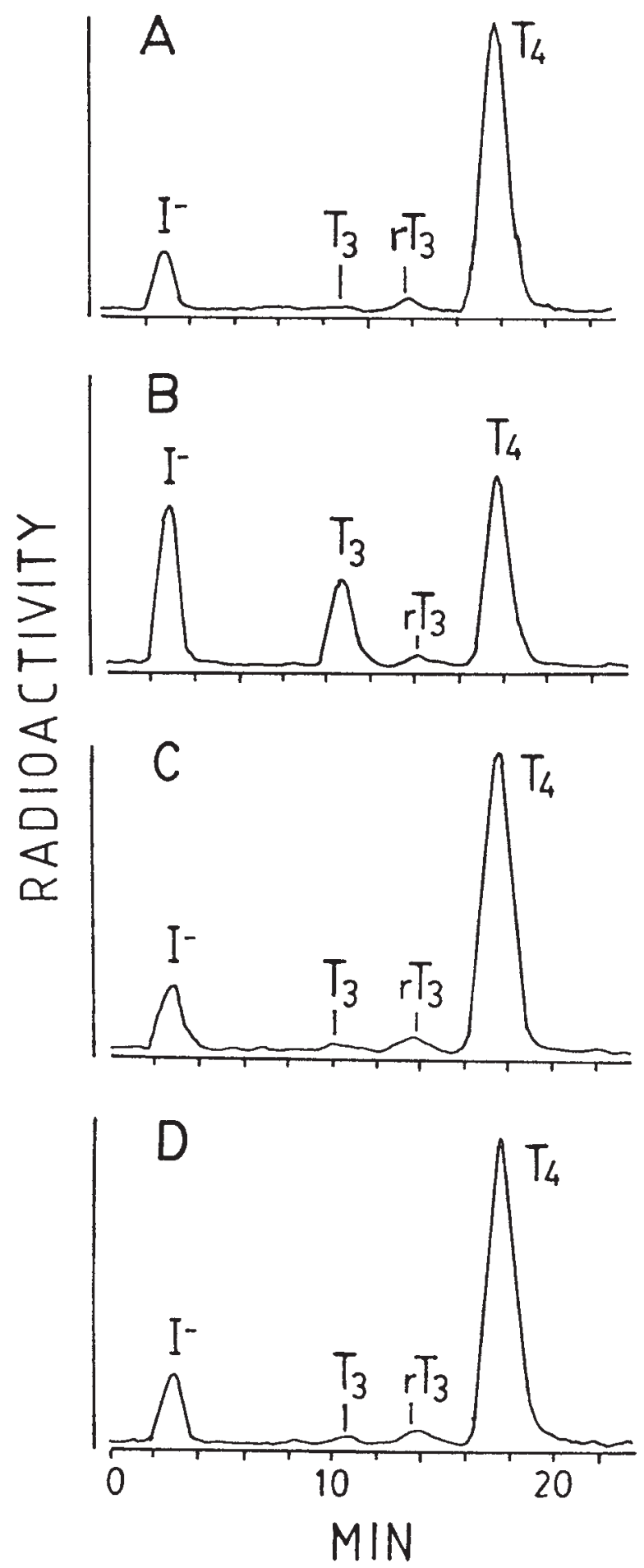

Fig. 1. HPLC radioactivity profiles for extracts of incubates of $\left[{ }^{125} \mathrm{I}\right] \mathrm{T}_{4}$ and microsomes from hagfish tissues. Retention times of authentic $\mathrm{T}_{4}, \mathrm{~T}_{3}, \mathrm{rT}_{3}$, and $3,3^{\prime}-\mathrm{T}_{2}$ are shown; $\mathrm{I}^{-}$, radioiodide. HPLC conditions: C-18 $150 \times 4.6 \mathrm{~mm}$ Econosphere column at $30^{\circ} \mathrm{C}$; elution at $1 \mathrm{ml} / \mathrm{min}$ with $42 \%$ acetonitrile/ $58 \%$ water $(0.1 \%$ trifluoroacetic acid) from 1 to $10 \mathrm{~min}$ and then increasing linearly to $54 \%$ acetonitrile at $20 \mathrm{~min}$. (A) Control (no microsomes); (B) trout liver; (C) hagfish liver; (D) hagfish intestine. patic $\mathrm{T}_{4} \mathrm{ORD}$ activities were not enhanced when $0.5 \mathrm{M} \mathrm{NaCl}, 0.5 \mathrm{M} \mathrm{KCl}$, or $0.25 \mathrm{M} \mathrm{NaCl}+0.25 \mathrm{M}$ $\mathrm{KCl}$ was added to the standard buffer to create osmotic concentrations more closely matching those of hagfish body fluids. Therefore subsequent examinations of hagfish $\mathrm{T}_{4} \mathrm{ORD}$ properties focussed on liver and intestine using the standard assay buffer.

Hepatic and intestinal $\mathrm{T}_{4} \mathrm{ORD}$ activity, measured at $\mathrm{pH} 7.2$ and $20 \mathrm{mM}$ DTT, decreased with microsomal protein concentration from 0.1 to 0.5 $\mathrm{mg}$ protein $/ \mathrm{ml}$ (Fig. 2) but varied less above 0.5 $\mathrm{mg} / \mathrm{ml}$. Subsequent analyses were at $0.5-0.8 \mathrm{mg}$ protein/ml. At $\mathrm{pH} 7.2$, hepatic $\mathrm{T}_{4} \mathrm{ORD}$ activity was $<2 \mathrm{fmol} / \mathrm{hr} / \mathrm{mg}$ protein and uninfluenced by added DTT (1-50 mM; data not shown). In contrast, intestinal $\mathrm{T}_{4} \mathrm{ORD}$ activity increased with DTT concentration to $13 \mathrm{fmol} / \mathrm{mg} / \mathrm{hr}$ at $50 \mathrm{mM}$ DTT (Fig. 3). At $20 \mathrm{mM}$ DTT, hepatic $\mathrm{T}_{4} \mathrm{ORD}$ activity was maximal at $\mathrm{pH} 7.0$ (Fig. 4A), whereas intestinal $\mathrm{T}_{4} \mathrm{ORD}$ activity was maximal at $\mathrm{pH}$ 9.0, the highest $\mathrm{pH}$ measured. Subsequent intestinal $\mathrm{T}_{4} \mathrm{ORD}$ and $\mathrm{T}_{4} \mathrm{IRD}$ activities (determined in the same incubate) were measured at $\mathrm{pH} 8.0$, which gives close to optimal activity for both pathways.

At near-optimal conditions ( $\mathrm{pH} 8.0$ and DTT 20 $\mathrm{mM}$ for intestine; $\mathrm{pH} 7.0$ and $20 \mathrm{mM}$ DTT for liver), only intestine showed enough $\mathrm{T}_{4} \mathrm{ORD}$ activity (10-12 fmol/hr/mg protein) to assess effects of inhibitors and analogues. $\mathrm{T}_{4} \mathrm{ORD}$ activity showed dose-dependent and similar degrees of inhibition by 6 - $n$-propyl-2-thiouracil (PTU) and iodoacetate (IAC) and was completely inhibited by 3 and $10 \mu \mathrm{M}$ aurothioglucose (ATG) (Fig. 5A). Dose-dependent inhibition was observed for all analogues except 3,5,3'-triiodothyroacetic acid (TRIAC) (Fig. 6A). The order of inhibition for 100$\mathrm{nM}$ analogue concentrations was $\mathrm{T}_{4}>\mathrm{rT}_{3}=3,5,3^{\prime}$, $5^{\prime}$-tetraiodothyroacetic acid (TETRAC) $>\mathrm{T}_{3}>3,5$ diiodothyronine $\left(3,5-\mathrm{T}_{2}\right)>$ TRIAC.

$\mathrm{T}_{4} \mathrm{IRD}$ activity for Study 1 was in the same low range $(\leq 5 \mathrm{fmol} / \mathrm{mg}$ protein $/ \mathrm{hr}$ ) for hagfish tissues as for trout liver $\mathrm{T}_{4} \mathrm{IRD}(4 \mathrm{fmol} / \mathrm{mg}$ protein/hr), but no $\mathrm{T}_{4} \mathrm{IRD}$ activity was detected in hagfish tissues for Study 2 (Table 1; Fig. 1). Hepatic $\mathrm{T}_{4} \mathrm{IRD}$ activity appeared maximal for liver at $\mathrm{pH} 7.0$ and for intestine at $\mathrm{pH} 8.0$ (Fig. 4B). Varying DTT concentration (1-50 mM) did not consistently enhance $\mathrm{T}_{4} \mathrm{IRD}$ activities (data not shown). Intestinal $\mathrm{T}_{4} \mathrm{IRD}$ activity at $\mathrm{pH} 8.0$ and $20 \mathrm{mM}$ DTT was completely inhibited by 10,100 , or $1000 \mu \mathrm{M}$ PTU 


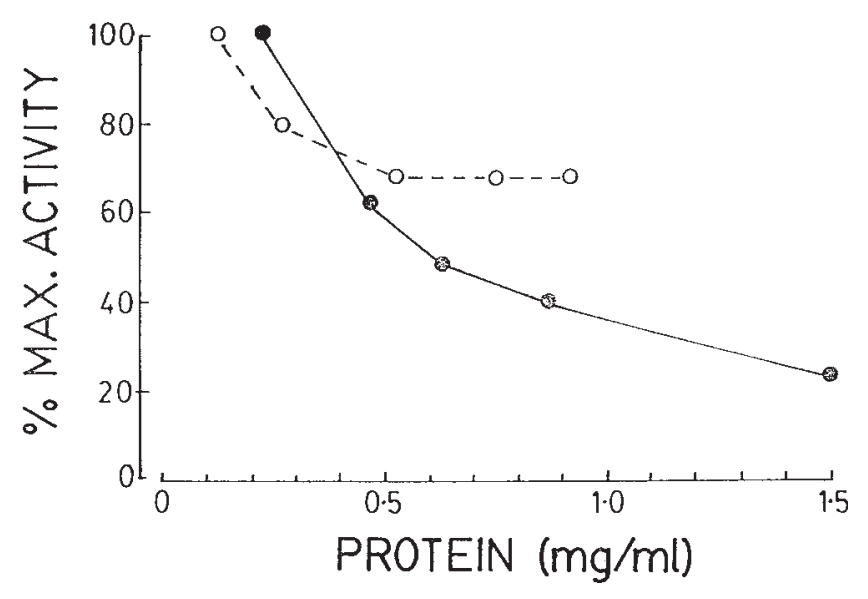

Fig. 2. Effects of microsomal protein concentration on $\mathrm{T}_{4} \mathrm{ORD}$ activity (expressed as a percentage of the maximum obtained for each tissue) for intestine $(\bullet)$ and liver $(\bigcirc)$. Each point represents the mean of closely agreeing duplicate measurements.

and showed dose-dependent inhibition with ATG and IAC (Fig. 5B).

\section{$T_{3}$ substrate}

No $\mathrm{T}_{3} \mathrm{ORD}$ activity was observed in hagfish tissues or in trout liver. $\mathrm{T}_{3}$ IRD activity was detected in all hagfish tissues but at levels below those for trout liver (Table 1; Fig. 7). Hagfish hepatic $\mathrm{T}_{3} \mathrm{IRD}$ activity was low or negligible at all DTT concentrations (data not shown), but intestinal $\mathrm{T}_{3} \mathrm{IRD}$ activity increased with increasing DTT to $50 \mathrm{mM}$ (Fig. 3). $\mathrm{T}_{3} \mathrm{IRD}$ activity was maximal at $\mathrm{pH} 7.0$ for both liver and intestine (Fig. 4C). Intestinal and hepatic $\mathrm{T}_{3} \mathrm{IRD}$ activities were not enhanced by $0.5 \mathrm{M} \mathrm{NaCl}, 0.5 \mathrm{M} \mathrm{KCl}$, or $0.25 \mathrm{M} \mathrm{NaCl}+0.25$ $\mathrm{M} \mathrm{KCl}$ addition to the standard buffer to create osmotic concentrations matching more closely those of hagfish body fluids. Intestinal $\mathrm{T}_{3} \mathrm{IRD}$ was strongly inhibited by ATG and IAC but not by PTU (Fig. 5C) and it was inhibited by $\mathrm{T}_{3}$ and TRIAC, less strongly by $\mathrm{T}_{4}$ and TETRAC, and only slightly by $\mathrm{rT}_{3}$ and $\mathrm{T}_{2}$ (Fig. $6 \mathrm{~B}$ ).

\section{$r T_{3}$ substrate}

We observed no $\mathrm{rT}_{3} \mathrm{ORD}$ or $\mathrm{rT}_{3} \mathrm{IRD}$ activities for brain, liver, muscle, or intestine during 2 $\mathrm{hr}$ of incubation using $0.4 \mathrm{nM} \mathrm{rT}_{3}$ at $\mathrm{pH} 7.2$ and $20 \mathrm{mM}$ DTT.

\section{DISCUSSION $T_{4}$ substrate}

Hagfish $\mathrm{T}_{4} \mathrm{ORD}$ properties for intestine and liver resembled in several respects those described for certain tissues in the sea lamprey (Eales et al.,

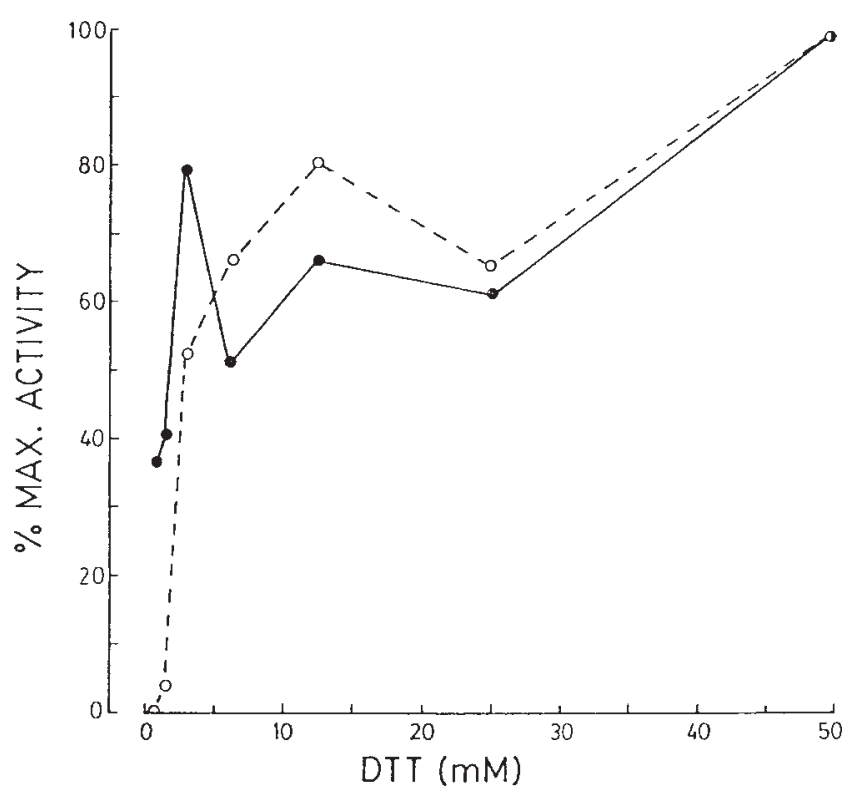

Fig. 3. Effects of DTT concentration in the incubate on intestinal $\mathrm{T}_{4} \mathrm{ORD}(\bullet)$ and $\mathrm{T}_{3} \mathrm{IRD}(\bigcirc)$ activities, expressed as a percentage of the maximum obtained for system. Each point represents the mean of closely agreeing duplicate determinations.

'97) and teleosts (MacLatchy and Eales, '92; Frith and Eales, '96; Cyr et al., '97; Mol et al., '98). The dependence on DTT and the TH analogue competition profile $\left(\mathrm{T}_{4}>\mathrm{rT}_{3}>\mathrm{T}_{3}\right)$ were similar for hagfish intestine and for larval lamprey liver and intestine (Eales et al., '97). However, while the hagfish hepatic $\mathrm{T}_{4} \mathrm{ORD} \mathrm{pH}$ optimum of 7 resembled that for other fish (MacLatchy and Eales, '92; Eales et al., '97; Mol et al., '97, '98), hagfish intestinal $\mathrm{T}_{4} \mathrm{ORD}$ activity was greatest at $\mathrm{pH} \mathrm{9,} \mathrm{the} \mathrm{highest} \mathrm{level}$ tested. Also, intestinal $\mathrm{T}_{4} \mathrm{ORD}$ was more sensitive to inhibition by PTU, IAC, and ATG than has been observed in other fish (Frith and Eales, '96; Eales et al., '97; Mol et al., '97, '98), although the order of inhibition (ATG > IAC > PTU) was the same. Thus hagfish $\mathrm{T}_{4} \mathrm{ORD}$ properties may show minor differences between tissues and minor differences from $\mathrm{T}_{4} \mathrm{ORD}$ properties of other fish.

The extremely low $\mathrm{T}_{4} \mathrm{ORD}$ activity could be due in part to the 2 -week fast before sampling. Fasting decreases $\mathrm{T}_{4} \mathrm{ORD}$ activity in rainbow trout but not to the low levels recorded for hagfish (Sweeting and Eales, '92b). Furthermore, Pacific hagfish (Eptatretus stouti) fasted respectively for $>100$ days or 38 days showed no decline in plasma $\mathrm{T}_{4}$ or $\mathrm{T}_{3}$ levels (Plisetskaya et al., '83a), suggesting that hagfish thyroidal status may be affected less by a prolonged fast than that of teleosts. Plasma $\mathrm{T}_{4}$ levels in fasted $M$. glutinosa were also similar 


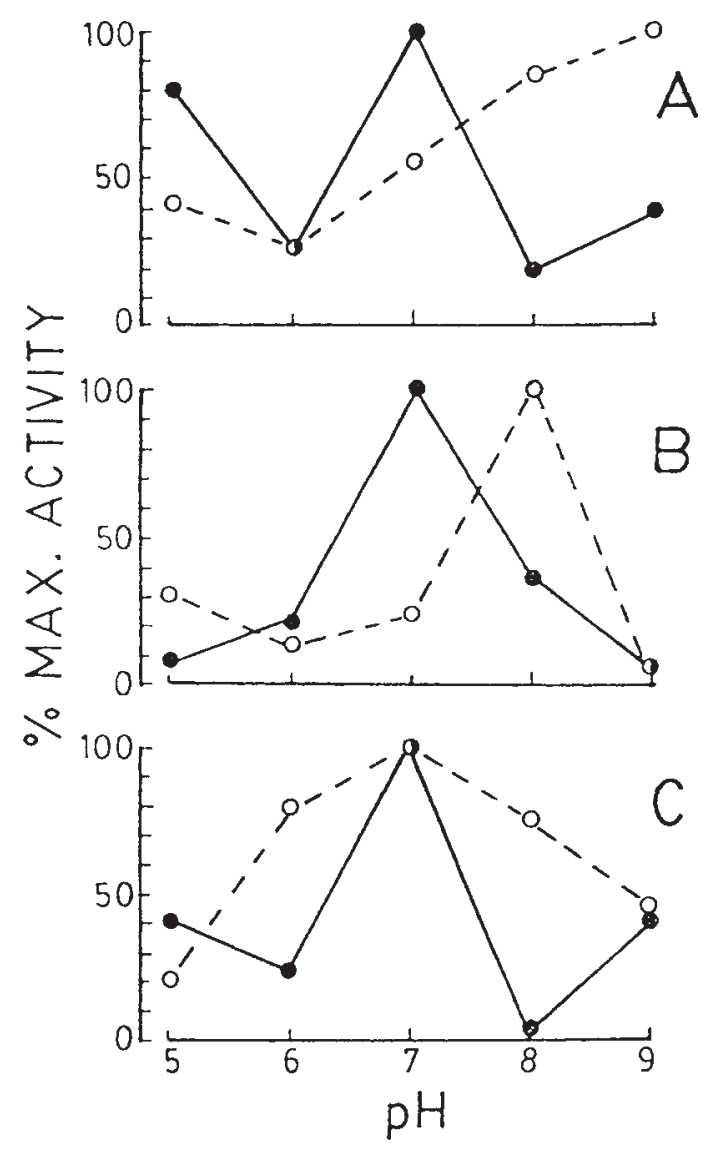

Fig. 4. Effects of incubation $\mathrm{pH}$ on deiodination activity (expressed as a percentage of the maximum obtained for each tissue) for hagfish intestine $(-)$ and liver $(\bigcirc)$. (A) $\mathrm{T}_{4} \mathrm{ORD}$ activity, (B) $\mathrm{T}_{4} \mathrm{IRD}$ activity, (C) $\mathrm{T}_{3} \mathrm{IRD}$ activity. Each point represents the mean of closely agreeing duplicate determinations.

to those of $E$. stouti (Henderson, '76). Some $\mathrm{T}_{4} \mathrm{ORD}$ activity may also have been lost during tissue storage for over 2 years at $-76^{\circ} \mathrm{C}$. We have found negligible loss of deiodination activity in trout liver stored at $-76^{\circ} \mathrm{C}$ for over 2 years (unpublished data), but hagfish deiodination has not been tested in this regard. Because of the low activity we could not conduct $\mathrm{T}_{4} \mathrm{ORD}$ kinetic analyses because higher substrate concentrations decreased the proportion of labeled $\mathrm{T}_{4}$ conversion below detection.

In most teleosts, the liver usually has the highest $\mathrm{T}_{4} \mathrm{ORD}$ activity (Morin et al., '94; Frith and Eales, '96; Cyr et al., '97; Mol et al., '98). However, hagfish $\mathrm{T}_{4} \mathrm{ORD}$ activity for intestine was about ten times that of liver. Similarly, both juvenile and adult sea lamprey, $P$. marinus, had greater intestinal than hepatic $\mathrm{T}_{4} \mathrm{ORD}$ activity (Eales et al., '97). Thus in these phyletically ancient extant craniates, the intestine may play a

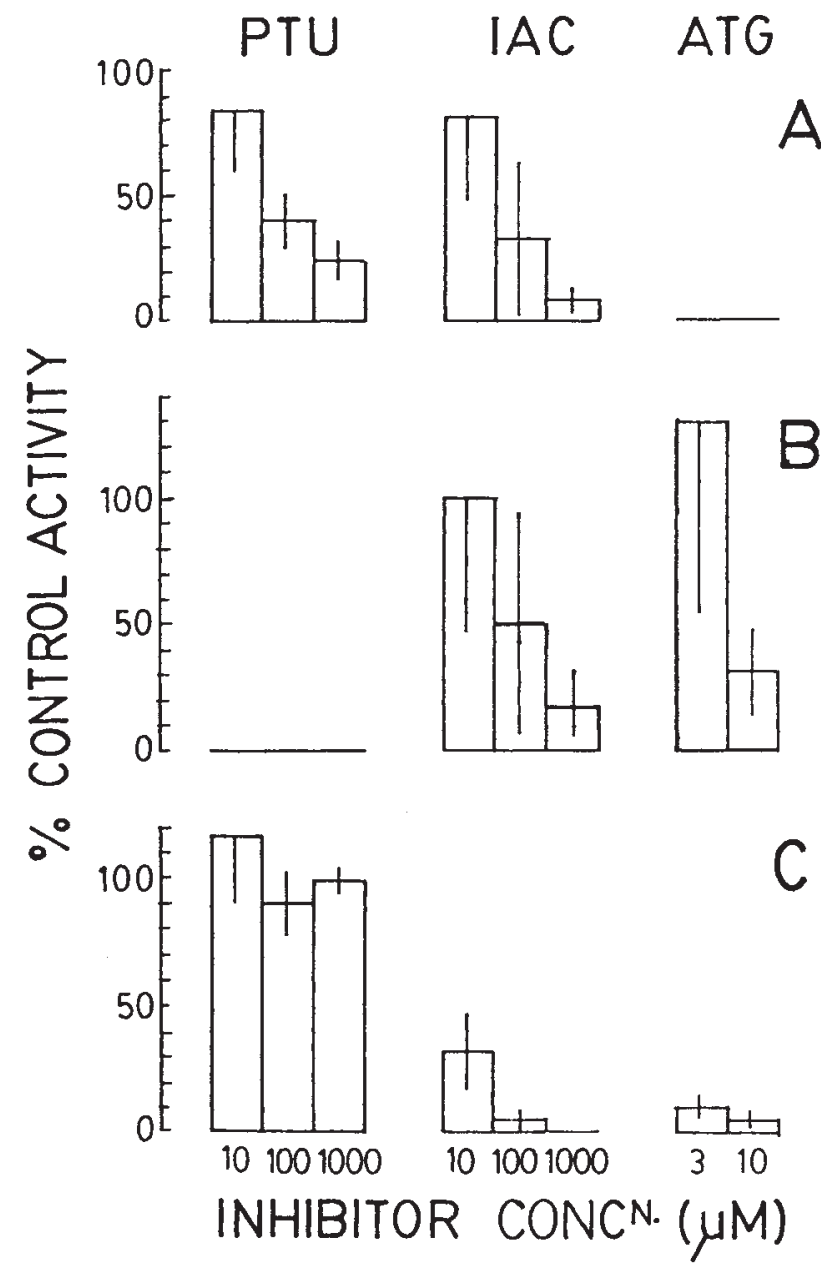

Fig. 5. Effects of PTU, IAC, and ATG on intestinal deiodination activity expressed as a percentage of the mean control activity (in the absence of inhibitor). (A) $\mathrm{T}_{4} \mathrm{ORD}$, (B) $\mathrm{T}_{4} \mathrm{IRD},(\mathrm{C}) \mathrm{T}_{3} \mathrm{IRD}$. Each bar represents the mean (SEM; $n=$ 2 or 3$) . \mathrm{T}_{4}=0.1-0.2 \mathrm{nM} ; \mathrm{T}_{3}=0.06-0.07 \mathrm{nM}$. Analyses were performed on 2 or 3 separate microsomal pools each derived from 3 intestines.

more important role in extrathyroidal regulation of thyroidal status.

Hagfish $\mathrm{T}_{4} \mathrm{IRD}$ activity, when detected, was relatively high in brain compared to other tissues. This resembles the pattern for rainbow trout (Frith and Eales, '96). Hagfish brain $\mathrm{T}_{4} \mathrm{IRD}$ activity (Study 1) was comparable to that of simultaneously assayed trout liver but 8 times lower than that predicted for trout brain based on measured kinetic values (Frith and Eales, '96). Although $\mathrm{T}_{4} \mathrm{IRD}$ activity was low, the $\mathrm{pH}$ optimum appeared different between liver and intestine. In contrast to all other fish deiodination systems studied to date, PTU was a more potent inhibitor than ATG or IAC (Frith and Eales, '96; Cyr et al., '97; Eales et al., '97; Mol et al., '97, '98). 


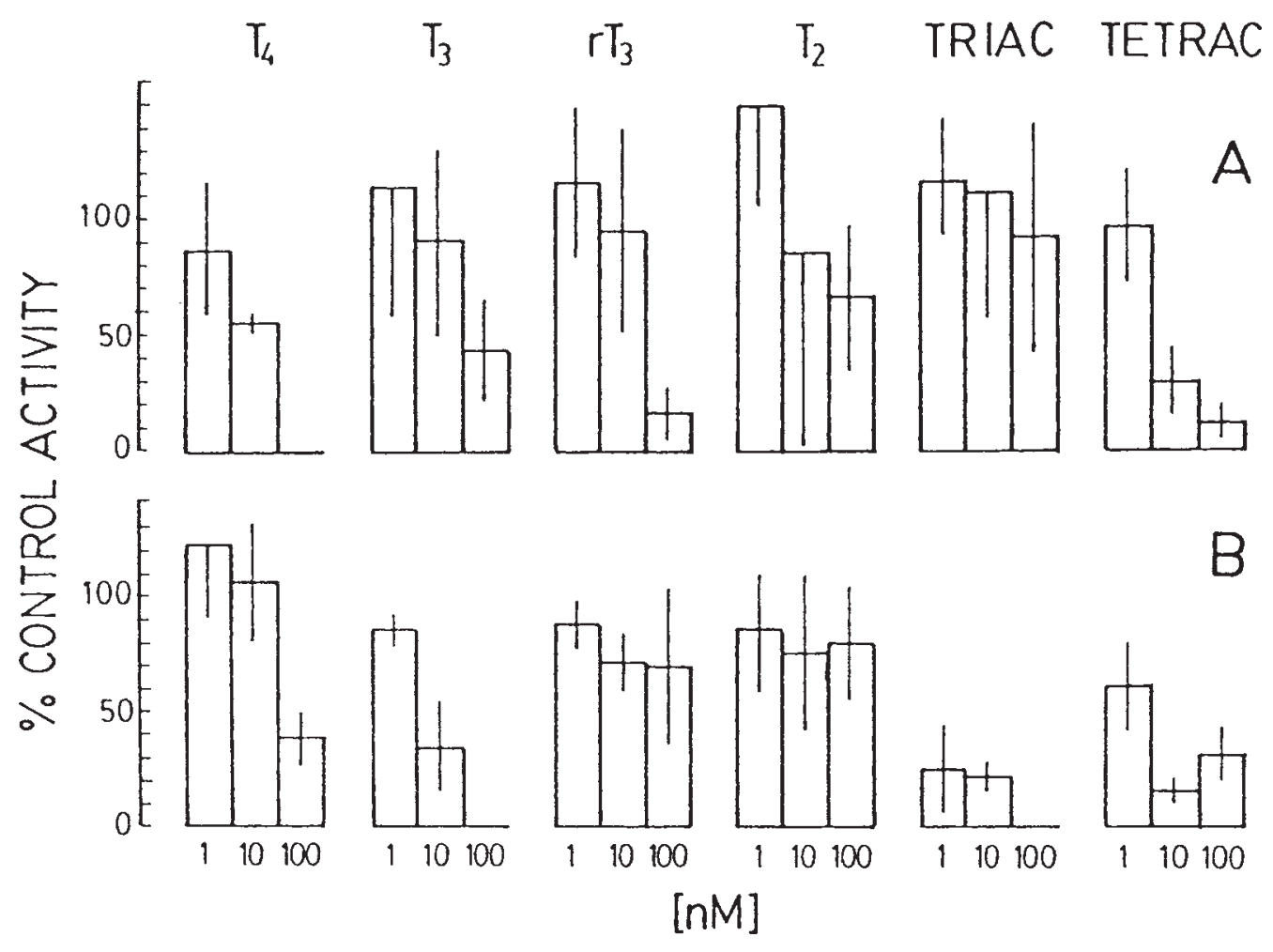

Fig. 6. Effects of unlabeled $\mathrm{T}_{4}, \mathrm{~T}_{3}, \mathrm{rT}_{3}, 3,5-\mathrm{T}_{2}$, TRIAC, and TETRAC $(1,10$, or $100 \mathrm{nM})$ on the proportion of labeled thyroid hormone $\left(\mathrm{T}_{4}=0.14 \mathrm{nM} ; \mathrm{T}_{3}=0.08-0.17 \mathrm{nM}\right)$ undergoing deiodination by hagfish intestine. The bars represent the mean

\section{$T_{3}$ substrate}

$\mathrm{T}_{3}$ IRD activity occurred in all hagfish tissues tested but was lower than for trout liver. Hagfish hepatic and intestinal $\mathrm{T}_{3} \mathrm{IRD}$ systems had similar $\mathrm{pH}$ optima and DTT requirements and closely resembled teleost $\mathrm{T}_{3} \mathrm{IRD}$ characteristics (Frith and Eales, '92; Mol et al., '97, '98). Thus during craniate evolution the properties of the $\mathrm{T}_{3}$ IRD system may have been more strongly conserved than those of the other deiodination systems. The differences in substrate preference, DTT requirement, $\mathrm{pH}$ optimum, and inhibition by PTU between hagfish $\mathrm{T}_{4} \mathrm{IRD}$ and $\mathrm{T}_{3} \mathrm{IRD}$ activities suggest that these two iodothyronine inner-ring deiodination pathways may be catalyzed by separate enzymes.

\section{$r T_{3}$ substrate}

In contrast to several teleost species (Valverde$\mathrm{R}$ et al., '97; Mol et al., '97, '98; Finnson et al., '99), no $\mathrm{rT}_{3} \mathrm{ORD}$ activity could be detected in any of the hagfish tissues tested at sub-nanomolar $\mathrm{rT}_{3}$ substrate levels. $\mathrm{rT}_{3}$ did compete with $\mathrm{T}_{4}$ in the
(SEM; $n=3$ ). One hundred percent represents the conversion in the absence of unlabeled hormones or their analogues. (A) $\mathrm{T}_{4} \mathrm{ORD}$, (B) $\mathrm{T}_{4} \mathrm{IRD}$, (C) $\mathrm{T}_{3} \mathrm{IRD}$. Analyses were performed on 2 or 3 separate microsomal pools each derived from 3 intestines.

$\mathrm{T}_{4}$ ORD pathway but the competition was negligible at $\mathrm{rT}_{3}$ concentrations of $10 \mathrm{nM}$ or lower. The negligible $\mathrm{rT}_{3} \mathrm{ORD}$ activity could be due to the fasting state of the hagfish. Alternatively, $\mathrm{rT}_{3} \mathrm{ORD}$ activity may serve mainly as a mechanism to conserve iodine (Finnson et al., '99), potentially an important function in freshwater or euryhaline fish species but possibly less so in the osmoconforming marine hagfish.

\section{CONCLUSIONS}

We have shown that liver, muscle, intestine, and brain of hagfish exhibit low-substrate enzymatic outer-ring and inner-ring deiodination of $\mathrm{T}_{4}$ and inner-ring deiodination of $\mathrm{T}_{3}$ but no deiodination of $\mathrm{rT}_{3}$. The extremely low deiodination activities are likely only partly due to fasting. Hagfish deiodinating systems share many properties with those of teleosts but may differ in minor respects. $\mathrm{T}_{3} \mathrm{IRD}$ appears the most highly conserved of the deiodinating systems. The relatively high specific activity of hagfish and lamprey intestinal deiodination suggests the intestine as a primary deiodination site in ancestral craniates. 

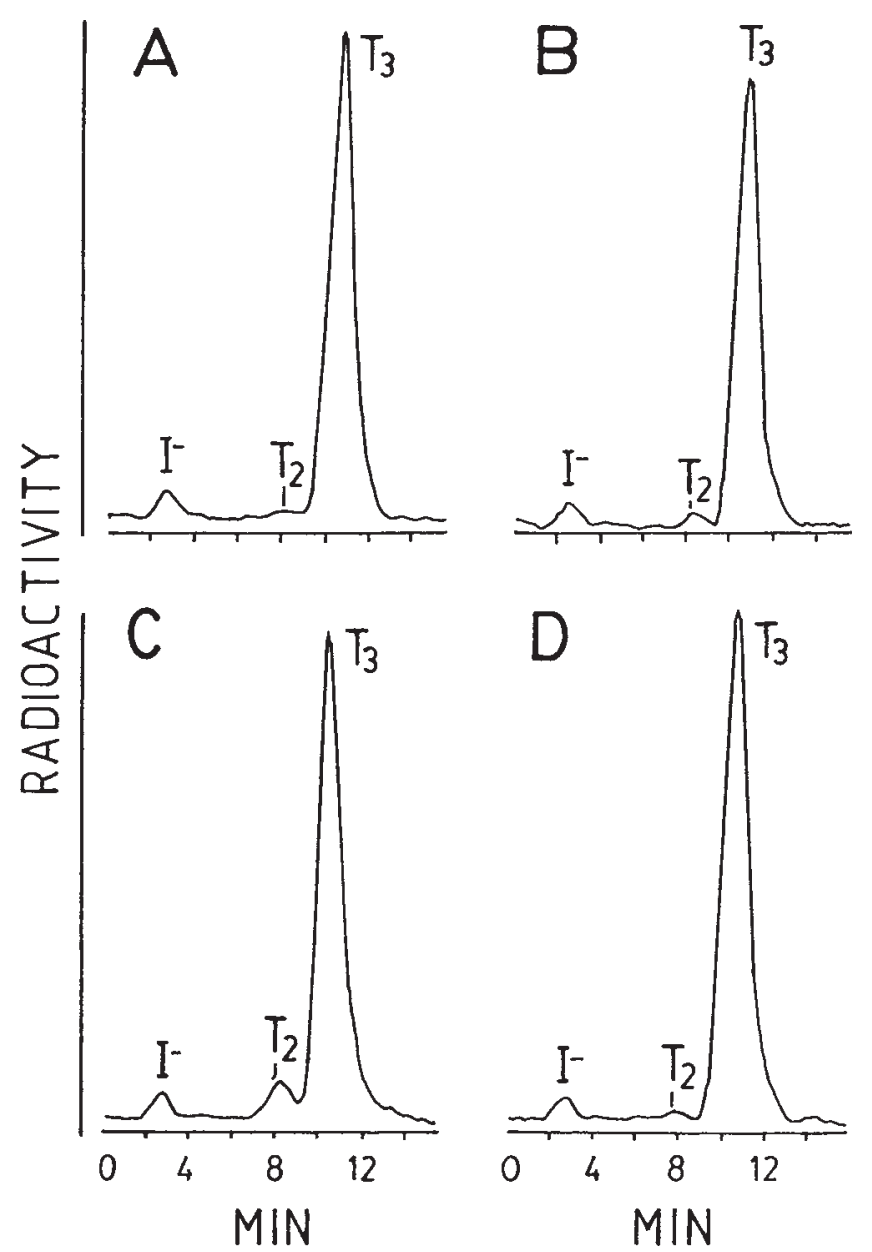

Fig. 7. HPLC radioactivity profiles for extracts of incubates of $\left[{ }^{125} \mathrm{I}\right] \mathrm{T}_{3}$ and microsomes from hagfish tissues. Retention times of authentic $\mathrm{T}_{3}, \mathrm{~T}_{2}$, and $\mathrm{I}^{-}$(radioiodide). HPLC conditions: $\mathrm{C}-$ $18150 \times 4.6 \mathrm{~mm}$ Econosphere column at $30^{\circ} \mathrm{C}$; elution at $1 \mathrm{ml} /$ min with $42 \%$ acetonitrile $/ 58 \%$ water $(0.1 \%$ trifluoroacetic acid $)$ from 0 to $10 \mathrm{~min}$ and then increasing linearly to $47 \%$ acetonitrile at $14 \mathrm{~min}$. (A) Control (no microsomes), (B) trout liver, (C) hagfish intestine, (D) hagfish liver.

\section{ACKNOWLEDGMENTS}

Hagfish were obtained courtesy of the Huntsman Marine Science Centre, St Andrews, New Brunswick, Canada. Ms. Audrey Waytiuk is thanked for laboratory assistance.

\section{LITERATURE CITED}

Cyr DG, Idler DR, McLeese JM, Eales JG. 1997. Effects of long-term temperature acclimation on deiodinase function, plasma thyroid hormone levels, growth and reproductive status of male Atlantic cod, Gadus morhua. Gen Comp Endocrinol 109:24-36.

Dickhoff WW, Gorbman A. 1977. In vitro thyrotropic effect of the pituitary of the Pacific hagfish, Eptatretus stouti. Gen Comp Endocrinol 31:75-79.

Dickhoff WW, Crim JW, Gorbman A. 1978. Lack of effect of synthetic thyrotropin releasing hormone on Pacific hagfish (Eptatretus stouti) pituitary-thyroid tissues in vitro. Gen Comp Endocrinol 35:96-98.

Dickhoff WW, Darling DA. 1983. Evolution of thyroid function and its control in lower vertebrates. Am Zool 23:697-707.

Eales JG. 1997. Iodine metabolism and thyroid-related function in organisms lacking thyroid follicles: are thyroid hormones also vitamins? Proc Soc Exp Biol Med 214:302-317.

Eales JG, Brown SB. 1993. Measurement and regulation of thyroidal status in teleost fish. Rev Fish Biol Fisher 3:299-347.

Eales JG, Holmes JA, McLeese JM, Youson JH. 1997. Thyroid hormone deiodination in various tissues of larval and upstream-migrant sea lampreys, Petromyzon marinus. Gen Comp Endocrinol 106:202-210.

Eales JG, McLeese JM, Holmes JA, Youson JH. 1999. Changes in intestinal and hepatic thyroid hormone deiodination during spontaneous metamorphosis of the sea lamprey, Petromyzon marinus. J Exp Zool 286:305-312.

Fernholm B, Olsson R. 1969. A cytopharmacological study of Myxine adenohypophysis. Gen Comp Endocrinol 13:336-356.

Finnson KW, McLeese JM, Eales JG. 1999. Deiodination and deconjugation of thyroid hormone conjugates and type I deiodination in liver of rainbow trout, Oncorhynchus mykiss. Gen Comp Endocrinol 115:387-397.

Forey P, Janvier P. 1993. Agnathans and the origin of jawed vertebrates. Nature 361:129-134.

Frith SD, Eales JG. 1996. Thyroid hormone deiodination pathways in brain and liver of rainbow trout, Oncorhynchus mykiss. Gen Comp Endocrinol 101:323-332.

Fujita H, Shinkawa Y. 1975. Electron microscopic studies of the thyroid gland of the hagfish, Eptatretus burgeri (a part of phylogenetic studies of the thyroid gland). Arch Histol Jpn 37:277-289.

Gorbman A. 1963. The Myxinoid thyroid gland. In: Brodel A, Krause R, editors. Biology of myxine. New York: Academic Press;. p 477-480.

Gorbman A. 1980. Evolution of the brain-pituitary relationship: evidence from the Agnatha. Can J Fish Aquat Sci 37:1680-1686.

Henderson NE. 1976. Thyroxine concentrations in plasma of normal and hypophysectomized hagfish, Myxine glutinosa (Cyclostomata). Can J Zool 54:180-184.

Henderson NE, Gorbman A. 1971. Fine structure of the thyroid follicle of the Pacific hagfish, Eptatretus stouti. Gen Comp Endocrinol 16:409-429.

Henderson NE, Lorscheider FL. 1975. Thyroxine and proteinbound iodine concentrations in plasma of the Pacific hagfish, Eptatretus stouti (Cyclostomata). Comp Biochem Physiol A51:723-726.

Leatherland JF. 1994. Reflections on the thyroidology of fishes: from molecules to humankind. Guelph Ichthyological Reviews, Vol. 2, THF. Neptune City, NJ: Publications Incorporated.

Kerkof PR, Boschwitz D, Gorbman A. 1973. The response of hagfish thyroid tissue to thyroid inhibitors and to mammalian thyroid-stimulating hormone. Gen Comp Endocrinol 21:231-240.

MacLatchy DL, Eales JG. 1992. Properties of $\mathrm{T}_{4} 5^{\prime}$-deiodinating systems in various tissues of rainbow trout, Oncorhynchus mykiss. Gen Comp Endocrinol 86:312-322.

McNabb FMA. 1992. Thyroid hormones. Englewood Cliffs, NJ: Prentice-Hall.

Mol KA, Kaptein E, Darras VM, de Greef WJ, Kuhn ER, Visser TJ. 1993. Different thyroid hormone-deiodinating 
enzymes in tilapia (Oreochromis niloticus) liver and kidney. FEBS Lett 321:140-144.

Mol KA, van der Geyten S, Darras VM, Visser TJ, Kuhn ER. 1997. Characterization of iodothyronine outer ring and inner ring deiodinase activities in the blue Tilapia, Oreochromis aureus. Endocrinology 138:1787-1793.

Mol KA, van der Geyten S, Burel C, Kuhn ER, Boujard T, Darras VM. 1998. Comparative study of iodothyronine outer ring and inner ring deiodinase activities in five teleostean fishes. Fish Physiol Biochem 18:253-266.

Morin P-P, Hara TJ, Eales JG. 1993 Outer- and inner-ring thyroxine deiodination in tissues of Atlantic salmon, Salmo salar, during photoperiodically induced parr-smolt transformation. Gen Comp Endocrinol 90:142-156.

Ohmiya Y, Suzuki S, Kondo Y. 1989. Isolation and characterization of hagfish thyroid iodoprotein by its non-thyroglobulin nature, very high iodine and carbohydrate contents and low hormone/iodine ratio. Eur J Biochem 182:11-18.

Orozco A, Silva JE, Valverde-R C. 1997. Rainbow trout liver expresses two iodothyronine phenolic ring deiodinase pathways with the characteristics of mammalian types I and II 5'-deiodinases. Endrocrinology 138:254-258.

Plisetskaya E, Dickhoff WW, Gorbman A. 1983a. Plasma thyroid hormones in cyclostomes: do they have a role in regulation of glycemic levels? Gen Comp Endocrinol 49:97-107.

Plisetskaya E, Woo NYS, Murat JC. 1983b. Thyroid hormones in cyclostomes and fish and their role in regulation of intermediary metabolism. Comp Biochem Physiol A74:179-187.

Sanders JP, van der Geyten S, Kaptein E, Darras VM, Kuhn ER, Leonard JL, Visser TJ. 1997. Characterization of a propylthiouracil-insensitive type I iodothyronine deiodinase. Endocrinology 138:5153-5160.
Shields CA, Eales JG. 1986. Thyroxine 5'-monodeiodinase activity in hepatocytes of rainbow trout, Salmo gairdneri: distribution, effects of starvation, and exogenous inhibitors. Gen Comp Endocrinol 63:334-343.

St. Germain DL, Galton VA. 1997. The deiodinase family of selenoproteins. Thyroid 7:655-668.

Suzuki S. 1982. Thyroid function in cyclostomes. Gunma Symposia on Endocrinology 19:13-28.

Suzuki S. 1985. Iodine distribution in the thyroid follicles of the hagfish, Eptatretus burgeri and lamprey, Lampetra japonica: electron-probe X-ray analysis. Cell Tissue Res 241:539-543.

Suzuki S, Gorbman A. 1974 Properties of an iodoprotein from thyroid tissue of the Pacific hagfish, Eptatretus stouti. Gen Comp Endocrinol 22:312-314.

Sweeting RM, Eales JG. 1992a. HPLC analysis of in vitro hepatic deiodination products of thyroid hormones in the rainbow trout, Oncorhynchus mykiss. Gen Comp Endocrinol 85:367-375.

Sweeting RM, Eales JG. 1992b. The effects of fasting and feeding on hepatic 5'-monodeiodinase activity in the rainbow trout, Oncorhynchus mykiss. Can J Zool 70:1516-1525.

Tong W, Kerkof P, Chaikoff IL. 1961. ${ }^{131}$ I utilization by thyroid tissue of the hagfish. Biochim Biophys Acta 52: 299-304.

Valverde-R C, Croteau W, LaFleur GJ Jr, Orozco A, St. Germain DL. 1997 Cloning and expression of a 5'-iodothyronine deiodinase from liver of Fundulus heteroclitus. Endocrinology 138:642-648.

Waterman AJ, Gorbman A. 1963. Thyroid tissues and some of its properties in the hagfish (Myxine glutinosa). Gen Comp Endocrinol 3:58-65. 